\title{
The Use of Unmanned Aerial Systems in Marine Mammal Research
}

\author{
Lorenzo Fiori $^{1, *}$, Ashray Doshi ${ }^{2}$, Emmanuelle Martinez ${ }^{3,4,5}$, Mark B. Orams ${ }^{6}$ \\ and Barbara Bollard-Breen ${ }^{2}$
}

1 New Zealand Institute of Applied Ecology, School of Applied Science, Auckland University of Technology, 46 Wakefield, WU Building, 1010 Auckland, New Zealand

2 New Zealand Conservation and Spatial Innovation Lab, School of Science, Auckland University of Technology, 46 Wakefield, WU Building, 1010 Auckland, New Zealand; ashray.doshi@aut.ac.nz (A.D.); barbara.breen@aut.ac.nz (B.B.-B.)

3 TriOceans, Marine Research and Technology Institute, Bay of Islands, New Zealand; manue@trioceans.org

4 Applied and Environmental Sciences Department, NorthTec, 0148 Whangarei, New Zealand

5 Coastal Marine Research Group, Institute of Natural and Mathematical Sciences, Massey University, 0632 Albany, New Zealand

6 School of Sport and Recreation, Auckland University of Technology, 0627 Northcote, New Zealand; mark.orams@aut.ac.nz

* Correspondence: lfiori@aut.ac.nz; Tel.: +64-27-365-8099

Academic Editors: Deepak R. Mishra and Prasad S. Thenkabail

Received: 14 March 2017; Accepted: 26 May 2017; Published: 30 May 2017

\begin{abstract}
Unmanned aerial systems (UAS), commonly referred to as drones, are finding applications in several ecological research areas since remotely piloted aircraft (RPA) technology has ceased to be a military prerogative. Fixed-wing RPA have been tested for line transect aerial surveys of geographically dispersed marine mammal species. Despite many advantages, their systematic use is far from a reality. Low altitude, long endurance systems are still highly priced. Regulatory bodies also impose limitations while struggling to cope with UAS rapid technological evolution. In contrast, small vertical take-off and landing (VTOL) UAS have become increasingly affordable but lack the flight endurance required for long-range aerial surveys. Although this issue and civil aviation regulations prevent the use of VTOL UAS for marine mammal abundance estimation on a large scale, recent studies have highlighted other potential applications. The present note represents a general overview on the use of UAS as a survey tool for marine mammal studies. The literature pertaining to UAS marine mammal research applications is considered with special concern for advantages and limitations of the survey design. The use of lightweight VTOL UAS to collect marine mammal behavioral data is also discussed.
\end{abstract}

Keywords: unmanned aerial systems; marine mammal abundance surveys; photogrammetry; photo-identification; cetacean behavior

\section{Introduction}

In the last decade, several studies have highlighted advantages and drawbacks of the use of lightweight unmanned aerial systems (UAS) for spatial ecology and wildlife monitoring (see respectively Anderson and Gaston [1] and Linchant et al. [2] for comprehensive reviews). In particular, UAS have been proposed as a tool for marine mammal surveys, as they allow researchers to reach remote areas and observe animals from an advantageous perspective, being less invasive than standard aircraft [3-9]. Despite the challenges of operating at sea [10], UAS have been used for a number of marine mammal research applications, from abundance surveys $[8,11-17]$ to the measurement of 
the individuals through photogrammetry methods $[4,8,9,13,18]$. Standard abundance estimates of marine mammals such as cetaceans, polar bears (Ursus maritimus), and ice seals rely on data collected surveying vast areas with low individual density, generally on board ships or aircraft, with high associated costs and risks for operators (e.g., [19-24]). Therefore, long-range fixed-wing UAS have been tested as a potential replacement of manned aircraft $[10,14,15,17,25]$. Aerial photogrammetry is a valuable method to gain indication of the health status of individuals extracting measurements of animal bodies from high resolution pictures taken from above (e.g., [4,9,26,27]). Unfortunately, this method is costly and can cause disturbances for the targeted animals, as it requires standard aircraft to fly over them [28-31]. In contrast, small vertical take-off and landing (VTOL) UAS have been proved to be an affordable, effective, and less invasive alternative to manned helicopters $[4,8,9]$. Furthermore, UAS have been proposed as a novel tool for the study of cetacean behavior $[6,17,32]$. Although the testing phase has been considered successful for close-range surveys and their use is being standardized, long-range missions still face several limitations. For instance, United States government agencies, such as the National Oceanic and Atmospheric Administration (NOAA), have been systematically using VTOL UAS for several marine mammal surveys since 2014 [10]. In contrast, the use of UAS for long-range surveys is under debate as the advantages provided by long endurance aircraft are offset by high operative costs and difficulties to obtain beyond visual line of sight (BVLOS) permits from the relevant civil aviation authorities $[7,10,15]$. In this note, we present a general overview of three UAS classes that have been used for marine mammal surveys and the relevant literature. Advantages and limitations are highlighted for each class and application. Finally, we discuss the use of VTOL UAS as a novel tool to study marine mammal behavior.

\section{Unmanned Aerial Systems}

UAS consist of the unmanned aerial vehicle (UAV), the sensor or payload carried, and the ground control station (GCS) [33]. The GCS includes launching and retrieving platforms that can be mounted on vessels or land transported on trailers. UAS classification derives exclusively from existing military descriptions [33]. UAS classes valuable for marine mammal research and details relevant for survey design are reported in this note:

- Low altitude long endurance (LALE) UAS. Fixed-wing aircraft capable of long endurance $(>4 \mathrm{~h})$ at low altitude ( $<3000 \mathrm{~m}$ above ground level, AGL). Small aircraft ( $<4 \mathrm{~m}$ wingspan; $2 \mathrm{~kg}$ payload capacity; $<20 \mathrm{~kg}$ take-off weight, Figure 1);

- Low altitude short endurance (LASE) UAS. Fixed-wing aircraft capable of short endurance (1-2 h) at low altitude. Generally, these aircraft are generally smaller than LALE $(<2.5 \mathrm{~m}$ wingspan; $<1 \mathrm{~kg}$ payload; $<5 \mathrm{~kg}$ take-off weight), electrically powered and-in some cases—can be hand-launched (Figure 2);

- VTOL UAS. VTOL class ranges from nano-aircraft fitting into the breadth of a hand, to larger unmanned helicopters. Electric-powered helicopters with multiple rotors are becoming increasingly popular and generally have from three to eight propellers (Figures 3 and 4).

\section{Low Altitude Long Endurance (LALE) UAS}

LALE UAS are the best candidates for long-range aerial surveys of geographically dispersed marine mammal species. Small fixed-wing aircraft can be handled by two operators and do not necessarily require an airstrip to take off or land (launching and retrieving equipment can be also mounted on a vessel). Further, fuel-powered engines ensure a flight duration, which can range from six to more than twenty hours, depending on the RPA and the payload weight.

A case in point is the Insitu (Boeing) Insight A-20 (ScanEagle ${ }^{\circledR}$, Figure 1), which represents the top of the market in terms of flight duration $(28 \mathrm{~h})$ and range $(150 \mathrm{~km})$. So far, it has been tested for dugong (Dugong dugon) [15] and humpback whale (Megaptera novaeangliae) [17] aerial abundance surveys in Australia, and seal counts in the Bering Sea pack ice [14]. Simulations have also been run with inflatable 
kayaks as whale-like targets [25]. These studies highlight the great potential of the ScanEagle ${ }^{\circledR}$ and LALE UAS. For instance, the possibility of keeping a permanent record of the survey with high-quality images may reduce significantly the "perception" bias, the human error component resulting in the underestimation of the sample [34]. Furthermore, the dugong and humpback whale sighting rate appeared to be less affected by the sea state, which normally happens in manned surveys [22,34], and every sighting was precisely GPS referenced. Nevertheless, the authors agree that the strip width is narrower than what is normally achieved during manned surveys. Consequently, UAS take around three hours to cover the same area, which two observers on an aircraft would cover in one hour flying at the same altitude [14,35,36]. Hodgson, et al. [15] proposed, therefore, the use of higher resolution cameras or multiple cameras to address this problem. However, the latter solution would significantly increase the payload weight and reduce the flight duration. In addition, the large amount of imagery recorded can lead to high post-processing costs [11] and represents a challenge in terms of time and efficiency of the analysis [2,36]. The studies presented in this note did not provide any exhaustive comparisons with manned aerial surveys, apart from noting that fuel consumption is significantly less for RPA $[14,15]$ and the costs for running UAS operations are similar for manned aircraft surveys [17]. Since they hired a UAS operator, they did not make the initial investment required to purchase a complete system and obtain the necessary certifications. Even choosing a cheaper UAS than the ScanEagle ${ }^{\circledR}$, the price tag of a single aircraft is currently above $\$ 100,000$ (US\$) and more than one backup is necessary to cover the risk of loss or damage [35]. Moreover, Moreland, et al. [14] noted that long flights in arctic and sub-arctic regions are prone to icing risk and precautions have to be taken to prevent RPA failures. To our knowledge, no data have been published regarding the use of other LALE UAS in marine mammal surveys. Further comparisons with manned aerial surveys are, however, necessary to evaluate whether the choice of LALE UAS can be economically competitive. Preliminary results have shown that UAS transport to remote locations costs more than using a standard aircraft already in place, not to mention the time and personnel necessary to analyze several hours of recorded imagery [36]. Finally, the use of LALE UAS for long-range marine mammal surveys is currently limited by safety issues relating to any activity taking place inside controlled airspace. Aviation authorities refrain from issuing BVLOS permits to prevent collisions with other airspace users $[12,14,15,33,35]$. This not only limits the UAS operation range, but also their potential to reach remote areas [15].

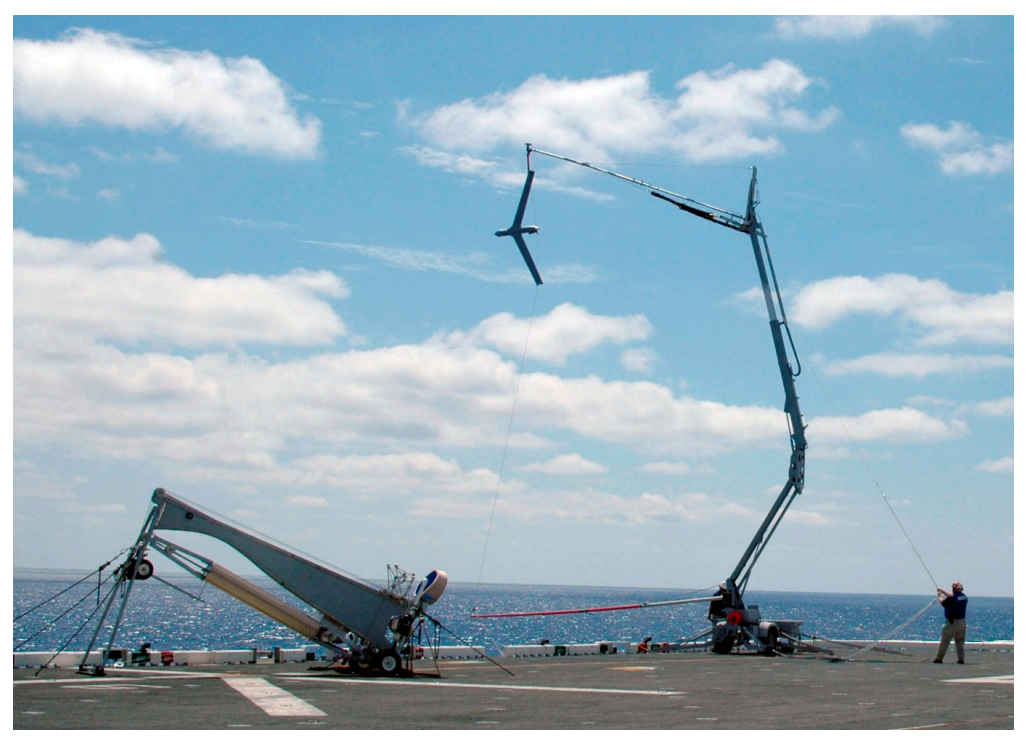

Figure 1. ScanEagle ${ }^{\circledR}$ unmanned aerial vehicle (UAV) (Boeing Insitu, Bingen, WA, USA) lands on skyhook for recovery. The SuperWedge ${ }^{\circledR}$ pneumatic launching catapult (left) can be mounted on vessels. (C) United States Navy. 


\section{Low Altitude Short Endurance (LASE) UAS}

Several authors have proposed the use of short endurance fixed-wing RPA or LASE UAS (Figure 2) as survey platforms in open areas for big land Mammals (e.g., [37-39]), reptiles (e.g., [16]), and birds (e.g., [40-42]). In spite of their short endurance (generally 40-90 min), LASE UAS present several advantages with respect to long endurance systems or LALE UAS. Their price is significantly lower, with the average cost of a complete system, including the launching device and the GCS, being currently approximately $\$ 20,000$ (US\$). Some RPA can be hand-launched (e.g., [37,39,43,44]), as the airframe has a take-off weight lower than $5 \mathrm{~kg}$. Most of the aircraft land on their belly and thus require runaways. Web-retrieving systems have been developed for rear-propulsion aircraft, as belly-landings strongly reduce the airframe lifespan [38] and runaways can be dangerous for bystanders [45]. Such retrieving webs can fit on vessels and, therefore, allow an extension of the UAS operation range [35]. Another advantage with respect to long endurance UAS is the propulsion system. Electric brushless motors require less maintenance than fuel-powered engines [45], and are far quieter. The electric power, however, limits these aircraft. Advances in materials used for lithium batteries (e.g., [46,47]) may significantly improve the flight duration although, at the present time, the gain of weight resulting from carrying high capacity batteries often offsets the gain in endurance.

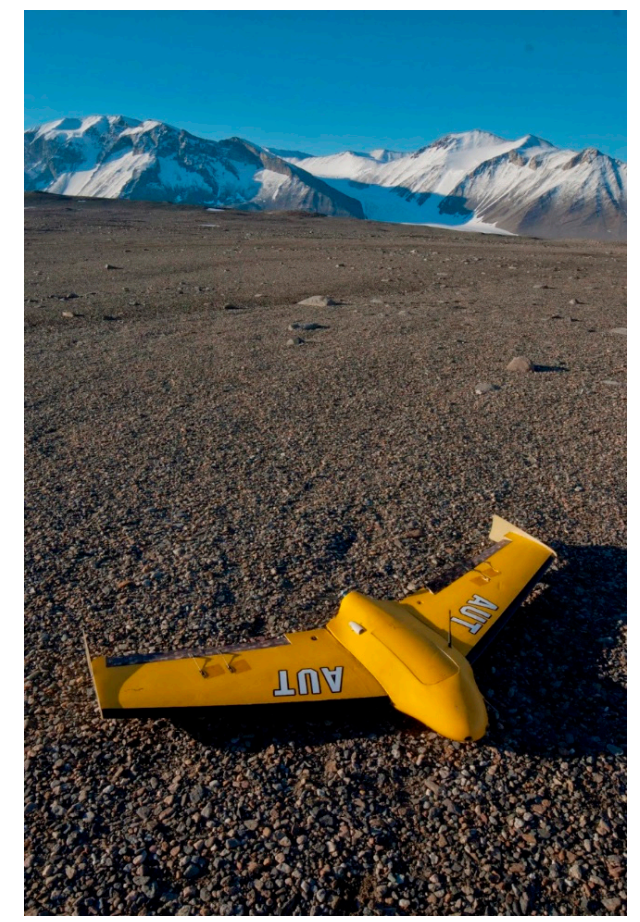

Figure 2. PolarFox UAV (Skycam UAV Ltd., Dunedin, New Zealand) can be hand launched with a bungee cord. It is equipped with a parachute for landing [44].

Koski et al. [7] published a study evaluating the use of a LASE UAS, Brican Flight Systems' TD100E, as a tool for photo-identification of bowhead whales (Balaena mysticetus). Five tests have been performed, flying from 120 to $210 \mathrm{~m}$ AGL, and using a GoPro and a Nikon D800 (50 mm lens) as sensors. Interestingly, the effective picture resolution, or ground sampling distance (GSD) (3.25 and $4.14 \mathrm{~cm} /$ pixel at 120 and $210 \mathrm{~m}$ altitude, respectively) was much higher than what was previously achieved from a manned aircraft, and clarity of details would allow the whale identification. In addition, when flying at such altitudes, the electric brushless motor is almost inaudible at sea level, and no whale's response to the aircraft was detected during the survey. Koski et al. [7] further reported a maximum flight duration of $2 \mathrm{~h}$. In contrast to the other short endurance UAV considered in this 
note, the TD100E is relatively large (4.9 m wingspan; $9.1 \mathrm{~kg}$ payload; $22.7 \mathrm{~kg}$ max take-off weight). A catapult launcher is therefore required to take off and a runaway has to be established in a field nearby the operation area.

Turning to lighter fixed-wing designs, the eBee (SenseFly) has been used for the census of grey seals (Halichoerus grypus) in two breeding colonies of the Gulf of St. Lawrence, Nova Scotia, Canada [11]. The aircraft was equipped with a Canon S110 and thermal infrared camera $(640 \times 512$-pixel resolution), obtaining a GSD of $3 \mathrm{~cm} /$ pixel and $7 \mathrm{~cm} /$ pixel, respectively. Pix $4 \mathrm{D}$ software was then used to create tridimensional orthomosaics with the recorded imagery, and the counts conducted by human analysts were compared with the results obtained by an automated detection model. The two census methods gave similar results (within $95 \%$ and $98 \%$ in the two locations), with most of the discrepancies being associated with the detection and discrimination of seal pups. The model has been proved to be an effective and less expensive alternative to human census, provided that the targeted animals thermally contrast with the landscape and are not associated with similar species [11].

Given the operational constraints highlighted so far, it is evident that LASE UAVs cannot provide a survey platform suitable for long-range marine mammal abundance estimation. Instead, LASE UAS could be used to survey narrower areas [37], such as marine mammal aggregation sites (e.g., breeding or molting pinniped colonies, cetacean seasonal aggregations; e.g., [11,48]). Without the need to rapidly cover extensive areas, the aircraft can be flown at lower altitude, potentially outside the controlled airspace ( $<400$ feet, $121.92 \mathrm{~m} \mathrm{AGL}$ ), thus obtaining the necessary flight authorization would be easier. Finally, the image resolution power would significantly increase, allowing the collection of more information (e.g., age class, size, marks) from the sightings, in a non-invasive way.

\section{Vertical Take-Off and Landing (VTOL) UAS}

Multirotor, electric-powered, helicopters show a remarkable flight stability if compared to fixed-wing UAVs, which allows high quality videos and pictures to be taken. Also, the small size of the airframe and the propellers make it easy to launch and retrieve the RPA in confined spaces without posing a big danger to the operators. Furthermore, small multirotor VTOL UAS are easily transportable, as there is no need for sophisticated equipment to take-off and land, and the GCS are normally the size of a laptop. Hovering flight, however, requires a large amount of power and their endurance is often limited to less than one hour, even for the most sophisticated RPA. In this note we concentrate on small VTOL RPA (1-5 kg), equipped with electric brushless motors, normally four or more, as they present several important features, which may be relevant to marine mammal research.

\subsection{Abundance Surveys, Photogrammetry, and Photo-Identification}

Perryman et al. [48] and Goebel et al. [8] investigated the use of a small customized hexacopter $(\mathrm{APH}-22)$ in the abundance estimation of seals in Antarctica. High-resolution $(<1 \mathrm{~cm} /$ pixel with $45 \mathrm{~mm}$ lens at $45 \mathrm{~m}$ altitude) images of the shore were used to count individuals and discriminate pups from adults in fur seal (Arctocephalus gazella) and Weddell seal (Leptonychotes weddellii) colonies. In addition, it was possible to measure with a high level of precision the size of some leopard seals (Hydrurga leptonyx). Focusing on the noise impact, no reaction of pinnipeds was observed while flying at $23 \mathrm{~m}$ AGL. NOAA has also been using the APH-22 for land and boat-based surveys on gray whales (Eschrictius robustus), southern resident killer whales (Orcinus orca) [9], and blue whales (Balaenoptera musculus) [18]. The authors suggest that flying at $35-40 \mathrm{~m}$ above the surface level allows the gathering of important information about size, health, and behavior, while reducing disturbance levels and increasing the measurement precision if compared with manned aircraft [9]. Image resolution ( $<1.4 \mathrm{~cm} /$ pixel with $25 \mathrm{~mm}$ lens at $35 \mathrm{~m}$ altitude) was slightly lower than what was achieved by Goebel et al. [8], but enough to discriminate individuals and detect changes of their body condition during subsequent encounters [9].

A more recent study tested three different VTOL UAS platforms for the photo-identification and the measurement of gray seals (Halichoerus grypus) and harbor seals (Phoca vitulina) in the UK [13]. 
The photo-identification of gray seals was proven to be feasible flying at $30 \mathrm{~m}$ AGL. In contrast with the results of Goebel et al. [8], aerial measures of animals' total body length were, however, significantly imprecise, differing from the ground direct measures by more than the $2 \%$, even when seals were lying on boards. Pomeroy et al. [13] also described different reactions of the seals to the RPA, even for groups of animals of the same species, approached by the same airframe. Age, sex, and-in the case of gray seals-the breeding or molting condition, seem to affect the intensity of the behavioral responses. Interestingly, this study emphasized how the need for higher image resolution $(<0.2 \mathrm{~cm} /$ pixel $)$ may lead to the choice of larger camera sensors. This could mean that more lift power and larger aircraft are required, thereby raising the noise levels and, consequently, increasing the risk of stress for the animals. Alternatively, the RPA can be flown at lower altitude, even though increased visual and acoustic stimuli might cause disturbance of the targeted specimens. In addition, Pomeroy et al. [13] pointed out that in absence of wind the aircraft noise is not masked and is more obvious.

Christiansen et al. [4] tested a small waterproof quadcopter (Splashdrone, www.swellpro.com, Figure 3) in Western Australia to measure humpback whales. The authors demonstrated that high resolution aerial photographs of whales can be used to assess the body condition of whales and estimate the energetic cost of reproduction. Notably, animals were approached with the research vessel to use its size as scale for the photographs. Alternatively, the implementation of laser range finders attached to the aircraft has been proposed [49]. Furthermore, Christiansen et al. [3] performed tests for the underwater and airborne noise levels generated by Splashdrone flying at different heights. This procedure is a recommended practice in the assessment of noise impacts on wildlife [50,51], and should represent an essential first step in the design of marine mammal surveys involving the use of UAVs. The authors suggested that noise ( $95 \mathrm{~dB}$ re $\mu \mathrm{Pa} \mathrm{rms}$ ) may be heard underwater by toothed and baleen whales when flying at $10 \mathrm{~m}$ AGL or lower, but the effect is likely to be small, even for animals close to the surface [3].

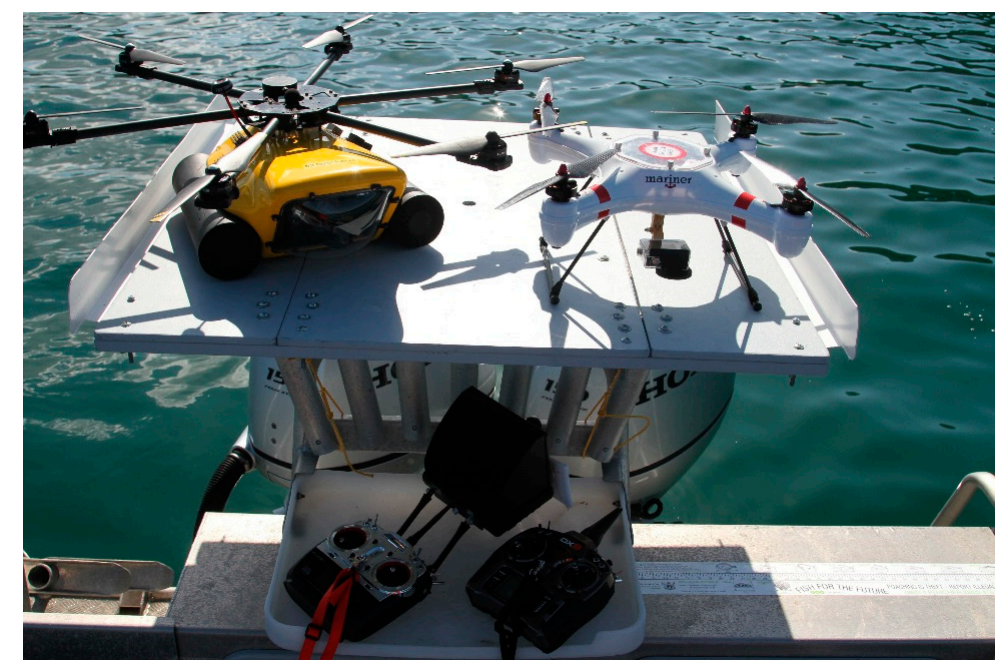

Figure 3. HexH2O ${ }^{\text {тм }}$ (XtremeVision360, Worthing, UK) (left) and Splashdrone (SwellPro, Shenzhen, China) (right) on custom built foldable helipad.

\subsection{Whale Plume Sampling and Behavioral Studies}

Acevedo-Whitehouse et al. [52] proposed the use of waterproof customized quadcopters to collect exhaled breath condensate from whales. The condensate can be an important source of information, as it contains dead cells (DNA) and hormones, which normally requires more invasive techniques such as remote biopsy in order to obtain such samples. However, the waterproof VTOL UAS market is still in its infancy, and only a few such RPA are available off-the-shelf, such as Splashdrone (SwellPro). While Splashdrone is available for less than \$2000 (US\$), its flight endurance is quite 
limited (approximately $12 \mathrm{~min}$ ). In addition, the small size of the sealed unit allows little further implementation. To address this issue, Auckland University of Technology (AUT) is currently testing a waterproof hexacopter $\left(\mathrm{HexH} 2 \mathrm{O}^{\mathrm{TM}}\right.$, Figures 3 and 4$)$ as a tool to investigate the behavior of bottlenose dolphins (Tursiops truncatus) [53] and humpback whales [54].

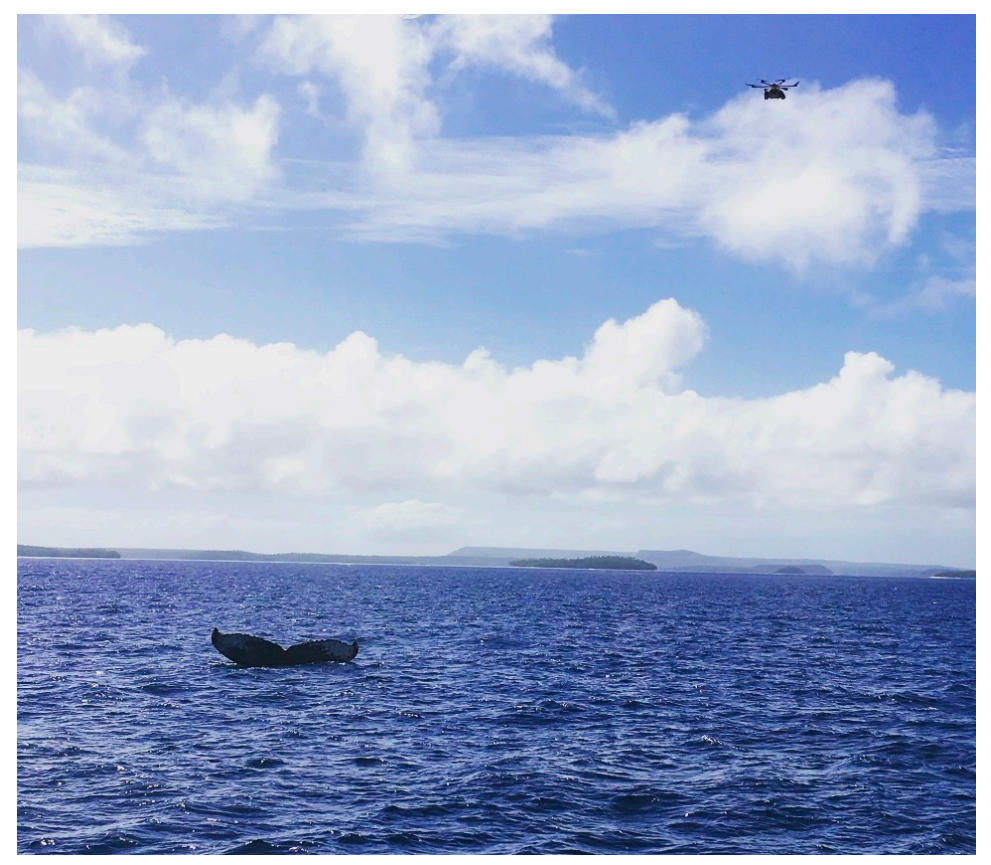

Figure 4. HexH2O ${ }^{\mathrm{TM}}$ has been used to observe the behavior of humpback whales in their Tongan breeding ground around the Vava' $u$ archipelago [54].

For this purpose, the aircraft can be deployed from a foldable platform mounted on a small vessel. Furthermore, the hexacopter is able to land and take off on the sea surface, keeping the engines well above the floating line and, therefore, reducing potential damage by minimizing their contact with saltwater. A large watertight compartment can also fit a couple of Li-Po batteries (6500-7000 mAh each), which ensure a flight time of approximately $25 \mathrm{~min}$ in good weather conditions. Preliminary results have already highlighted how the aerial imagery allows for the detection of the precise number of animals present in the pod and their age classes [53]. In contrast, the standard boat-based estimates are often biased, as the animals are not readily identifiable and they rarely breathe synchronously [21]. Additionally, important behaviors that normally take place underwater and are therefore invisible from a boat-based platform, such as socializing, foraging, and nursing [32], are observable from above (Figure 5). Finally, tests are also being performed for flights at different heights to assess the potential behavioral responses of targeted animals to the aircraft presence [53]. To this date, the disturbance levels on the overflown animals have been poorly investigated and they should be assessed from other survey platforms, rather than the source of potential disturbance itself $[29,31]$. This represents a common issue of the detection of marine mammal behavioral responses to manned aircraft. In particular, several factors that affect the responses have to be considered, such as the targeted species [30], ecotypes and individuals [55], the aircraft type [29], and the behavioral state at the time of the exposure [30]. Moreover, the acoustic stimuli can be modulated by characteristic of the surveyed area, such as sea state, wind speed, and geomorphology of the coastal environment [5]. 


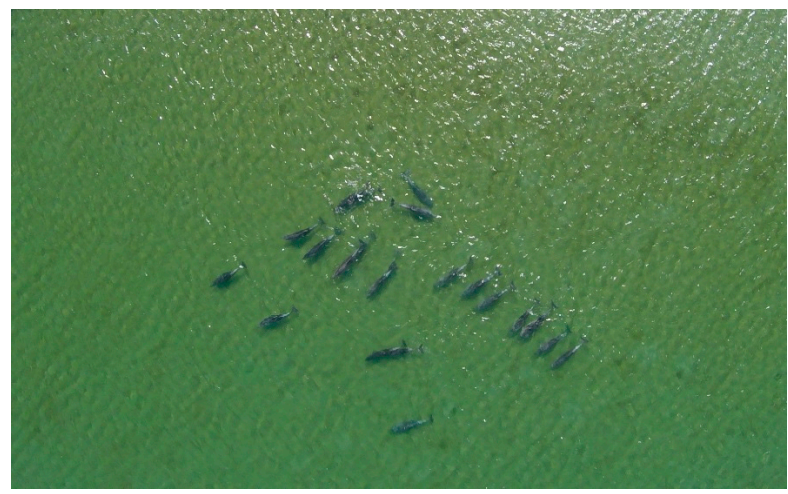

(a)

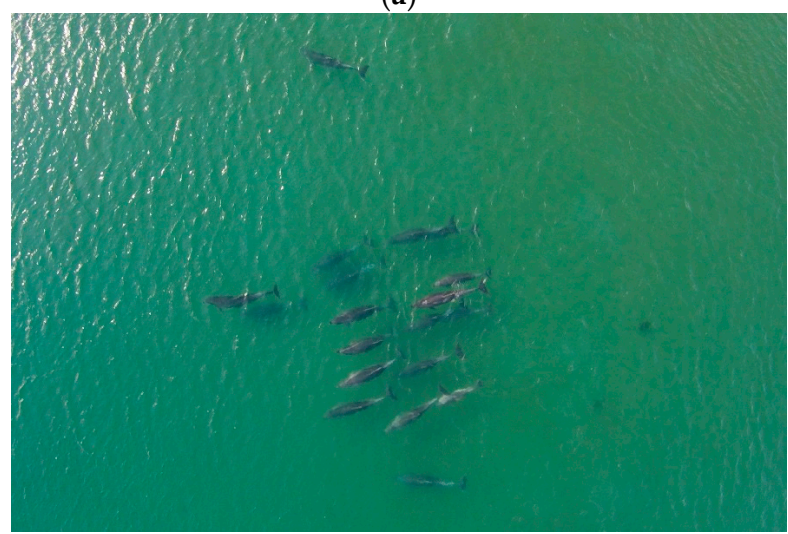

(b)

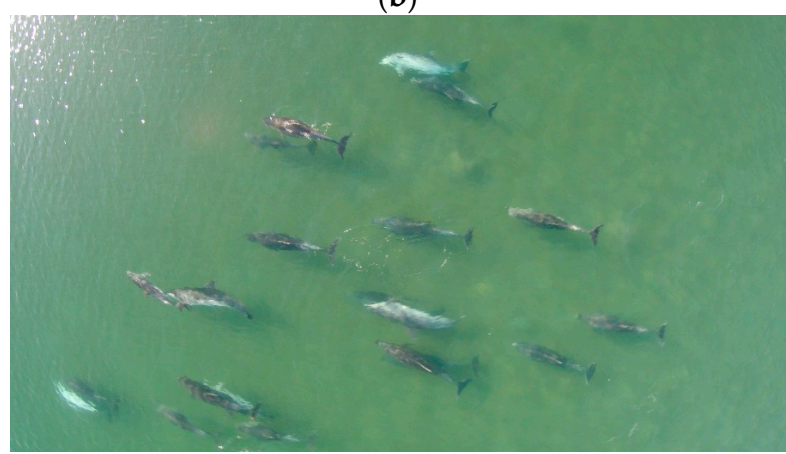

(c)

Figure 5. Bottlenose dolphins photographed in Blind Bay, Great Barrier Island, New Zealand $\left(36^{\circ} 15^{\prime} \mathrm{S}\right.$, $175^{\circ} 26^{\prime}$ E), during UAV disturbance tests at (a) $40 \mathrm{~m}$; (b) $25 \mathrm{~m}$; and (c) $10 \mathrm{~m}$ of altitude [53].

The idea of combining boat observation with aerial imagery for marine mammal behavior surveys is not new. In the early 2000s, several studies on manatees (Trichechus manatus latirostris) and bottlenose dolphins were conducted using a video camera mounted on a tethered, helium-filled aerostat, also called a "blimp" [56-59]. This approach highlighted the possibility of following the animals during the time spent underwater, depending on depth and water turbidity [57,58]. The "blimp" methodology, however, presents some disadvantages when compared with multirotor VTOL UAS. First of all, the shadow of the "blimp" caused behavior disruptions in dugongs [60], manatees, and bottlenose dolphins [58]. While this may also represent an issue for multirotor aircraft, the aircraft is considerably smaller in size than the "blimp" [60]. Secondly, the aerial observation range was limited to a radius of approximately $200 \mathrm{~m}$ around the vessel [60], while small multirotor aircraft can be controlled at distances of about $4 \mathrm{~km}$. Therefore, it is possible to observe animals in a disturbance-free context and effectively eliminate the research boat presence bias (e.g., [61]). 


\section{Unmanned Aerial System Regulations}

The International Civil Aviation Organization (ICAO) established guidelines to standardize UAS regulation worldwide through standard and recommended practices [62]. In many countries, aircraft under $25 \mathrm{~kg}$ of weight at take-off are considered small-RPA and have less strict regulations. Regardless of the weight, all operations have to obtain a certificate or waiver of authorization (CoA) in order to take place and operators must be certified for flying RPA. These requirements apply to operations outside controlled airspace, if they are not recreational flights. In the United States, CoA and UAS controller certification exemptions are granted to recreational users complying with the guidelines summarized below:

- $\quad$ Outside controlled airspace: fly below 400 feet or $121.92 \mathrm{~m}$ above ground level (AL);

- Airport no fly zone (NFZ): do not fly closer than 5 nautical miles or $9.26 \mathrm{~km}$ to airports;

- $\quad$ Fly in visual line of sight (VLOS): always maintain visual line of sight on the UAS;

- City NFZ: do not fly over densely populated areas;

- Building/vehicles NFZ: maintain safe distance from building and vehicles on the flight path.

Satisfying recreational use guidelines in commercial UAS operations, including scientific research, gives a remarkable boost to CoA assessment by a civil aviation authority. Nevertheless, those interested in using UAS for scientific research should contact the relevant regulatory bodies to clarify legal and safety issues in relation to the area and the methodology of the study. These factors are not negligible and have to be addressed in the early stages of the survey design conception.

\section{Conclusions}

Unmanned aerial systems or UAS represent a revolutionary tool for marine mammal research. Long endurance fixed-wing RPA can replace manned aircraft for line transect aerial surveys, minimizing the human risk component and allowing researchers to access remote areas $[14,15,17,36]$ (Table 1). However, the issues highlighted in this note are not negligible. That is, regulations and costs still pose a serious limitation to the systematic use of LALE UAS. While it is reasonable to expect further lowering of LALE UAS costs, it is also necessary that the civil aviation authorities accommodate the regulations to the recent advances in RPA technology, leading to an increase in their commercial use [33,35]. A first step in this direction has been taken by the US Federal Aviation Administration (FAA) with the amendment of UAS regulations in 2016 [63]. Waivers for commercial, and therefore research, UAS operations are now issued by the FAA for surveys taking place outside the controlled airspace. However, BVLOS permits are still extremely complicated to obtain and limited to remote locations [10].

Turning to smaller RPA, LASE UAS are a less expensive tool suitable for close-range abundance surveys of marine mammal aggregation sites [11] (Table 1). LASE UAS deployment in offshore waters is also feasible, provided that vessels can be equipped with adequate retrieving systems [35]. Otherwise, VTOL UAS are more affordable ( $<\$ 15,000$ (US\$), GCS included) and maneuverable systems that can be operated safely even from small research vessels $(<6 \mathrm{~m})$. Lightweight VTOL UAS have been successfully used for photo-identification, photogrammetry, and counts of marine mammals (Table 1). GDS of less than $1 \mathrm{~cm}$ /pixel have been proven to be achievable flying at $45 \mathrm{~m}$ AGL [8], and even higher resolution can be obtained by lowering flight altitude, or by increasing sensor size and focal length $[10,13]$. Image resolution requirements to be met should be assessed prior to choosing the surveying VTOL platform, and GDS calculators are available to assist this process (e.g., Pix4D). However, a conservative approach is recommended, as environmental factors, flight parameters, and aircraft specifications can lower the effective resolution [10]. In addition to photogrammetry and censuses, we support the idea that they can provide high-quality video of marine mammal behavior in a non-invasive way [17,32], and from a perspective that allows for the tracking of the position of the animals even when they are submerged [6]. 
Nevertheless, VTOL UAS may allow researchers to eliminate the research boat bias and, therefore, can be an invaluable survey tool for shore-based observers, especially when a land vantage point is not available. Despite their value for research, concerns have been raised regarding the risk of harassment for the targeted animals (e.g., $[5,13,64])$. Consequently, scientific best practices for the use of UAS in wildlife surveys are being developed in order to minimize the disturbance levels. That is, systematic assessment of the potential impacts on the targeted species is of paramount importance for the survey design $[3,5,65]$. Finally, the current low endurance of VTOL UAV still represents a limitation, requiring back-up options to be considered for long observations. When possible, traditional boat-based or land-based observation should be included in the survey design in order to collect data during the battery replacement time. Alternatively, the use of two aircraft can be a more expensive-but highly effective-solution.

The variety of UAS and sensors on the market provides a wide choice of alternatives. UAS should not only be considered as a potential replacement of the human component in marine mammal research, but also as a valuable tool for novel research approaches.

Table 1. The use of UAS in marine mammal research.

\begin{tabular}{|c|c|c|}
\hline Objective of the Study & UAS Class/Model & Sensor \\
\hline $\begin{array}{l}\text { Collection of exhaled breath condensate of large } \\
\text { whales [52] }\end{array}$ & VTOL $^{1} /$ Aquacopter & $\mathrm{N} / \mathrm{A}$ \\
\hline $\begin{array}{l}\text { Photogrammetry of Humpback whales } \\
\text { (Megaptera novaeangliae) [4] }\end{array}$ & VTOL $^{1} /$ Splashdrone & Canon PowerShot D30 \\
\hline $\begin{array}{l}\text { Photogrammetry of blue whales (Balaenoptera } \\
\text { musculus) [18] }\end{array}$ & VTOL $^{1} /$ APH-22 & $\begin{array}{l}\text { Olympus E-PM2 M.Zuiko } 25 \mathrm{~mm} \\
\text { F1.8 lens }\end{array}$ \\
\hline $\begin{array}{l}\text { Photogrammetry and photo-identification of } \\
\text { killer whales (Orcinus orca) [9] }\end{array}$ & VTOL $^{1} /$ APH-22 & $\begin{array}{l}\text { Olympus E-PM2 M.Zuiko } 25 \mathrm{~mm} \\
\text { F1.8 lens }\end{array}$ \\
\hline $\begin{array}{l}\text { Abundance surveys and photogrammetry of } \\
\text { seals in Antarctica }[8,48]\end{array}$ & VTOL $^{1}$ / APH-22 & $\begin{array}{c}\text { Sony NEX-5, Canon EOS-M, } \\
\text { Olympus E-P1; } 22 \mathrm{~mm} \text { or } 45 \mathrm{~mm} \\
\text { lens }\end{array}$ \\
\hline $\begin{array}{c}\text { Abundance surveys of dugongs (Dugong dugon) } \\
\text { [15] }\end{array}$ & LALE $^{2} /$ ScanEagle & Nikon D90; 35 mm lens \\
\hline $\begin{array}{c}\text { Abundance surveys of manatees (Trichechus } \\
\text { manatus latirostris) [16] }\end{array}$ & LASE $^{3} /$ FoldBat & Canon Elura 2 \\
\hline $\begin{array}{l}\text { Photo-identification of bowhead whales (Balaena } \\
\text { mysticetus) [7] }\end{array}$ & $\mathrm{LASE}^{3} / \mathrm{TD} 100-\mathrm{E}$ & Nikon D800; 35 mm lens \\
\hline $\begin{array}{l}\text { Abundance surveys of seals in the Bering Sea } \\
\text { pack ice [14] }\end{array}$ & LALE $^{2} /$ ScanEagle & Nikon D300; 35 mm lens \\
\hline $\begin{array}{l}\text { Abundance surveys, photogrammetry, and } \\
\text { photo-identification of seals in UK [13] }\end{array}$ & $\begin{array}{l}\text { VTOL }^{1} / \text { Cinestar } 6 \text { VTOL }^{1} / \text { Skijib } \\
\text { VTOL }^{1} / \text { Vulcan } 8\end{array}$ & Sony HDR-CX760 and PJ650 \\
\hline $\begin{array}{l}\text { Abundance surveys and photo-identification of } \\
\text { Steller sea lions (Eumetopias jubatus) [12] }\end{array}$ & VTOL $^{1} /$ APH-22 & $\begin{array}{c}\text { Canon EOS M; EF-M f } / 2 \text { STM } 22 \\
\text { mm lens }\end{array}$ \\
\hline $\begin{array}{l}\text { Abundance surveys of grey seals (Halichoerus } \\
\text { grypus) [11] }\end{array}$ & $\operatorname{LASE}^{3} / \mathrm{eBee}$ & $\begin{array}{l}\text { Canon S110; senseFly LCC } \\
\text { Thermomapper }\end{array}$ \\
\hline $\begin{array}{c}\text { Abundance surveys of humpback whales } \\
\text { (Megaptera novaeanlgiae) [17] }\end{array}$ & LALE $^{2} /$ ScanEagle & Nikon D90; 35 mm lens \\
\hline
\end{tabular}

Acknowledgments: No funds have been received for covering the costs to publish the manuscript in open access.

Author Contributions: Lorenzo Fiori conceived and wrote the paper; Ashray Doshi and Barbara Bollard-Breen reviewed the technical data presented in the manuscript; Mark Orams and Emmanuelle Martinez edited the script.

Conflicts of Interest: The authors declare no conflict of interest.

\section{References}

1. Anderson, K.; Gaston, K.J. Lightweight unmanned aerial vehicles will revolutionize spatial ecology. Front. Ecol. Environ. 2013, 11, 138-146. [CrossRef] 
2. Linchant, J.; Lisein, J.; Semeki, J.; Lejeune, P.; Vermeulen, C. Are unmanned aircraft systems (UASS) the future of wildlife monitoring? A review of accomplishments and challenges. Mamm. Rev. 2015, 45, 239-252. [CrossRef]

3. Christiansen, F.; Rojano-Doñate, L.; Madsen, P.T.; Bejder, L. Noise levels of multi-rotor unmanned aerial vehicles with implications for potential underwater impacts on marine mammals. Front. Mar. Sci. 2016, 3, 277. [CrossRef]

4. Christiansen, F.; Dujon, A.M.; Sprogis, K.R.; Arnould, J.P.Y.; Bejder, L. Noninvasive unmanned aerial vehicle provides estimates of the energetic cost of reproduction in humpback whales. Ecosphere 2016, 7, 1-18. [CrossRef]

5. Smith, C.E.; Sykora-Bodie, S.T.; Bloodworth, B.; Pack, S.M.; Spradlin, T.R.; LeBoeuf, N.R. Assessment of known impacts of unmanned aerial systems (UAS) on marine mammals: Data gaps and recommendations for researchers in the united states. J. Unmanned Veh. Syst. 2016, 4, 1-14. [CrossRef]

6. Nowacek, D.P.; Christiansen, F.; Bejder, L.; Goldbogen, J.A.; Friedlaender, A.S. Studying cetacean behaviour: New technological approaches and conservation applications. Anim. Behav. 2016, 120, 235-244. [CrossRef]

7. Koski, W.R.; Gamage, G.; Davis, A.R.; Mathews, T.; LeBlanc, B.; Ferguson, S.H. Evaluation of uas for photographic re-identification of bowhead whales, Balaena mysticetus. J. Unmanned Veh. Syst. 2015, 3, $22-29$. [CrossRef]

8. Goebel, M.E.; Perryman, W.L.; Hinke, J.T.; Krause, D.J.; Hann, N.A.; Gardner, S.; LeRoi, D.J. A small unmanned aerial system for estimating abundance and size of antarctic predators. Polar Biol. 2015, 38, 619-630. [CrossRef]

9. Durban, J.; Fearnbach, H.; Barrett-Lennard, L.; Perryman, W.; LeRoi, D. Photogrammetry of killer whales using a small hexacopter launched at sea. J. Unmanned Veh. Syst. 2015, 3, 131-135. [CrossRef]

10. Development and Use of Uass by the National Marine Fisheries Service for Surveying Marine Mammals; Marine Mammal Commission: Bethesda, MD, USA, 2016.

11. Seymour, A.C.; Dale, J.; Hammill, M.; Halpin, P.N.; Johnston, D.W. Automated detection and enumeration of marine wildlife using unmanned aircraft systems (UAS) and thermal imagery. Sci. Rep. 2017, 7, 45127. [CrossRef] [PubMed]

12. Sweeney, K.L.; Helker, V.T.; Perryman, W.L.; LeRoi, D.J.; Fritz, L.W.; Gelatt, T.S.; Angliss, R.P. Flying beneath the clouds at the edge of the world: Using a hexacopter to supplement abundance surveys of steller sea lions (Eumetopias jubatus) in Alaska. J. Unmanned Veh. Syst. 2015, 4, 1-12. [CrossRef]

13. Pomeroy, P.; O'Connor, L.; Davies, P. Assessing use of and reaction to unmanned aerial systems in gray and harbor seals during breeding and molt in the UK. J. Unmanned Veh. Syst. 2015, 3, 102-113. [CrossRef]

14. Moreland, E.E.; Cameron, M.F.; Angliss, R.P.; Boveng, P.L. Evaluation of a ship-based unoccupied aircraft system (uas) for surveys of spotted and ribbon seals in the bering sea pack ice. J. Unmanned Veh. Syst. 2015, 3, 114-122. [CrossRef]

15. Hodgson, A.; Kelly, N.; Peel, D. Unmanned aerial vehicles (UAVS) for surveying marine fauna: A dugong case study. PLOS ONE 2013, 8, e79556. [CrossRef] [PubMed]

16. Jones, G.P.; Pearlstine, L.G.; Percival, H.F. An assessment of small unmanned aerial vehicles for wildlife research. Wildl. Soc. Bull. 2006, 34, 750-758. [CrossRef]

17. Hodgson, A.; Peel, D.; Kelly, N. Unmanned aerial vehicles for surveying marine fauna: Assessing detection probability. Ecol. Appl. 2017. [CrossRef] [PubMed]

18. Durban, J.W.; Moore, M.J.; Chiang, G.; Hickmott, L.S.; Bocconcelli, A.; Howes, G.; Bahamonde, P.A.; Perryman, W.L.; LeRoi, D.J. Photogrammetry of blue whales with an unmanned hexacopter. Mar. Mamm. Sci. 2016, 32, 1510-1515. [CrossRef]

19. Rekdal, S.L.; Hansen, R.G.; Borchers, D.; Bachmann, L.; Laidre, K.L.; Wiig, O.; Nielsen, N.H.; Fossette, S.; Tervo, O.; Heide-Jorgensen, M.P. Trends in bowhead whales in West Greenland: Aerial surveys vs. Genetic capture-recapture analyses. Mar. Mamm. Sci. 2015, 31, 133-154. [CrossRef]

20. Panigada, S.; Lauriano, G.; Burt, L.; Pierantonio, N.; Donovan, G. Monitoring winter and summer abundance of cetaceans in the Pelagos Sanctuary (Northwestern Mediterranean Sea) through aerial surveys. PLoS ONE 2011, 6, e22878. [CrossRef] [PubMed]

21. Dawson, S.; Wade, P.; Slooten, E.; Barlow, J. Design and field methods for sighting surveys of cetaceans in coastal and riverine habitats. Mamm. Rev. 2008, 38, 19-49. [CrossRef]

22. Pollock, K.H.; Marsh, H.D.; Lawler, I.R.; Alldredge, M.W. Estimating animal abundance in heterogeneous environments: An application to aerial surveys for dugongs. J. Wildl. Manag. 2006, 70, 255-262. [CrossRef] 
23. Buckland, S.T.; Anderson, D.R.; Burnham, K.P.; Laake, J.L.; Borchers, D.L.; Thomas, L. Introduction to Distance Sampling: Estimating Abundance of Biological Populations; Chapman \& Hall: New York, NY, USA, 2001.

24. Hiby, L.; Lovell, P. Using aircraft in tandem formation to estimate abundance of harbour porpoise. Biometrics 1998, 54, 1280-1289. [CrossRef]

25. Koski, W.R.; Allen, T.; Ireland, D.; Buck, G.; Smith, P.R.; Macrander, A.M.; Halick, M.A.; Rushing, C.; Sliwa, D.J.; McDonald, T.L. Evaluation of an unmanned airborne system for monitoring marine mammals. Aquat. Mamm. 2009, 35, 347-357. [CrossRef]

26. Perryman, W.L.; Lynn, M.S. Evaluation of nutritive condition and reproductive status of migrating gray whales (Eschrichtius robustus) based on analysis of photogrammetric data. J. Cetacean Res. Manag. 2002, 4, 155-164.

27. Miller, C.A.; Best, P.B.; Perryman, W.L.; Baumgartner, M.F.; Moore, M.J. Body shape changes associated with reproductive status, nutritive condition and growth in right whales Eubalaena glacialis and E. Australis. Mar. Ecol. Prog. Ser. 2012, 459, 135-156. [CrossRef]

28. Smultea, M.A.; Mobley, J.R.J.; Fertl, D.; Fulling, G.L. An unusual reaction and other observations of sperm whales near fixed-wing aircraft. Gulf Carrabbean Res. 2008, 20, 75-80. [CrossRef]

29. Patenaüde, N.J.; Richardson, W.J.; Smultea, M.A.; Koski, W.R.; Miller, G.W.; Würsig, B.; Greene, C.R. Aircraft sound and disturbance to bowhead and beluga whales during spring migration in the alaskan beaufort sea. Mar. Mamm. Sci. 2002, 18, 309-335. [CrossRef]

30. Würsig, B.; Lynn, S.K.; Jefferson, T.A.; Mullin, K.D. Behaviour of cetaceans in the Northern Gulf of Mexico relative to survey ships and aircraft. Aquat. Mamm. 1998, 24, 41-50.

31. Richardson, W.J.; Würsig, B. Influences of man-made noise and other human actions on cetacean behaviour. Mar. Freshw. Behav. Physiol. 1997, 29, 183-209. [CrossRef]

32. Smultea, M.A.; Fertl, D.; Bacon, C.E.; Moore, M.R.; James, V.R.; Würsig, B. Cetacean mother-calf behavior observed from a small aircraft off southern California. Anim. Behav. Cognit. 2017, 4, 1-23.

33. Watts, A.C.; Ambrosia, V.G.; Hinkley, E.A. Unmanned aircraft systems in remote sensing and scientific research: Classification and considerations of use. Remote Sens. 2012, 4, 1671-1692. [CrossRef]

34. Marsh, H.; Sinclair, D.F. Correcting for visibility bias in strip transect aerial surveys of acquatic fauna. J. Wildl. Manag. 1989, 53, 1017-1024. [CrossRef]

35. Koski, W.R.; Abgrall, P.; Yazvenko, S.B. An inventory and evaluation of unmanned aerial systems for offshore surveys of marine mammals. J. Cetacean Res. Manag. 2010, 11, 239-247.

36. Angliss, R.P.; Ferguson, P.; Kennedy, A. Manned vs unmanned aerial surveys of cetaceans in the arctic: Operations and preliminary results. In Proceedings of the Noaa Uas Users Symposium, La Jolla, CA, USA, 25-27 October 2016.

37. Barasona, J.A.; Mulero-Pazmany, M.; Acevedo, P.; Negro, J.J.; Torres, M.J.; Gortazar, C.; Vicente, J. Unmanned aircraft systems for studying spatial abundance of ungulates: Relevance to spatial epidemiology. PLoS ONE 2014, 9, e115608. [CrossRef] [PubMed]

38. Vermulen, C.; Lejeune, P.; Lisein, J.; Sawadogo, P.; Bouche, P. Unmanned aerial survey of elephants. PLoS ONE 2013, 8, e54700. [CrossRef] [PubMed]

39. Mulero-Pazmany, M.; Stolper, R.; Van Essen, L.D.; Negro, J.J.; Sassen, T. Remotely piloted aircraft systems as a rhinoceros anti-poaching tool in africa. PLOS ONE 2014, 9, e83873. [CrossRef] [PubMed]

40. Chabot, D.; Craik, S.R.; Bird, D.M. Population census of a large common tern colony with a small unmanned aircraft. PLoS ONE 2015, 10, e0122588. [CrossRef] [PubMed]

41. Sarda-Palomera, F.; Bota, G.; Vinolo, C.; Pallares, O.; Sazatornil, V.; Brotons, L.; Gomariz, S.; Sarda, F. Fine-scale bird monitoring from light unmanned aircraft systems. IBIS 2012, 154, 177-183. [CrossRef]

42. Chabot, D.; Bird, D.M. Evaluation of an off-the-shelf unmanned aircraft system for surveying flocks of geese. Waterbirds 2012, 35, 170-174. [CrossRef]

43. Chabot, D.; Carignan, V.; Bird, D.M. Measuring habitat quality for least bitterns in a created wetland with use of a small unmanned aircraft. Wetlands 2014, 34, 527-533. [CrossRef]

44. Bollard-Breen, B.; Brooks, J.D.; Jones, M.R.L.; Robertson, J.; Betschart, S.; Kung, O.; Craig Cary, S.; Lee, C.K.; Pointing, S.B. Application of an unmanned aerial vehicle in spatial mapping of terrestrial biology and human disturbance in the McMurdo Dry Valleys, East Antarctica. Polar Biol. 2015, 38, 573-578. [CrossRef]

45. Funaki, M.; Hirasawa, N. Outline of a small unmanned aerial vehicle (ant-plane) designed for antarctic research. Polar Sci. 2008, 2, 129-142. [CrossRef] 
46. Wu, H.X.; Liu, Q.J.; Guo, S.W. Composites of graphene and lifepo4 as cathode materials for lithium-ion battery: A mini-review. Nano-Micro Lett. 2014, 6, 316-326. [CrossRef]

47. Kucinskis, G.; Bajars, G.; Kleperis, J. Graphene in lithium ion battery cathode materials: A review. J. Power Sources 2013, 240, 66-79. [CrossRef]

48. Perryman, W.L.; Goebel, M.E.; Ash, N.; LeRoi, D.J.; Gardner, S. Small Unmanned Aerial Systems for Estimating Abundance of Krill-Dependent Predators: A Feasibility Study with Preliminary Results; National Oceanic and Atmosferic Administration; Southwest Fisheries Science Center: La Jolla, CA, USA, 2014; pp. 64-72.

49. Dawson, S. Drone Success in Expedition Measuring Southern Right Whales; Department of Marine Science, University of Otago: Dunedin, New Zealand, 2016.

50. Pater, L.; Grubb, T.; Delaney, D.K. Recommendations for improved assessment of noise impacts on wildlife. J. Wildl. Manag. 2009, 73, 788-795. [CrossRef]

51. Southall, B.L.; Bowles, A.E.; Ellison, W.T.; Finneran, J.; Gentry, R.; Green, C.R.; Kastak, C.R.; Ketten, D.R.; Miller, J.H.; Nachtigall, P.E.; et al. Marine mammal noise exposure criteria: Initial scientific recommendations. Aquat. Mamm. 2007, 33, 411-521. [CrossRef]

52. Acevedo-Whitehouse, K.; Rocha-Gosselin, A.; Gendron, D. A novel non-invasive tool for disease surveillance of free-ranging whales and its relevance to conservation programs. Anim. Conserv. 2010, 13, 217-225. [CrossRef]

53. Fettermann, T. Assessing the behavioral responses of wild bottlenose dolphins (Tursiops truncatus) to a lightweight multirotor unmanned aerial vehicle (UAV). Unpublished work, Manuscript in preparation.

54. Fiori, L. Assessing the effects of humpback whale-based tourism in Vava'u, Kingdom of Tonga: Behavioral responses of whales to vessels and in-water tourism activities. Unpublished work.

55. Richter, C.F.; Dawson, S.; Slooten, E. Impacts of commercial whale watching on male sperm whales at kaikoura, new zealand. Mar. Mamm. Sci. 2006, 22, 46-63. [CrossRef]

56. Nowacek, S.M.; Wells, R.S.; Owen, E.C.G.; Speakman, T.R.; Flamm, R.O.; Nowacek, D.P. Florida manatees, Trichechus manatus latirostris, respond to approaching vessels. Biol. Conserv. 2004, 119, 517-523. [CrossRef]

57. Nowacek, D.P. Sequential foraging behaviour of bottlenose dolphins, Tursiops truncatus, in Sarasota Bay, FL. Behaviour 2002, 139, 1125-1145. [CrossRef]

58. Nowacek, D.P.; Tyack, P.L.; Wells, R.S. A platform for continuous behavioral and acoustic observation of free-ranging marine mammals: Overhead video combined with underwater audio. Mar. Mamm. Sci. 2001, 17, 191-199. [CrossRef]

59. Flamm, R.O.; Owen, E.C.G.; Owen, C.F.W.; Wells, R.S.; Nowacek, D. Aerial videogrammetry from a tethered airship to assess manatee life-stage structure. Mar. Mamm. Sci. 2000, 16, 617-630. [CrossRef]

60. Hodgson, A. Blimp-cam aerial video observations of marine mammals. Mar. Technol. Soc. J. 2007, 41, $39-43$. [CrossRef]

61. Guerra, M.; Dawson, S.M.; Brough, T.E.; Rayment, W.J. Effects of boats on the surface and acoustic behaviour of an endangered population of bottlenose dolphins. Endanger. Species Res. 2014, 24, 221-236. [CrossRef]

62. Unmanned Aircraft Systems (UAS). Available online: https://www.icao.int/Meetings/UAS/Documents/ Circular\%20328_en.pdf (accessed on 14 March 2017).

63. Operation and Certification of Small Unmanned Aircraft Systems; Transportation. Available online: https:/ / www.federalregister.gov/documents/2016/06/28/2016-15079/operation-and-certificationof-small-unmanned-aircraft-systems (accessed on 14 March 2017).

64. Ditmer, M.A.; Vincent, J.B.; Werden, L.K.; Tanner, J.C.; Laske, T.G.; Iaizzo, P.A.; Garshelis, D.L.; Fieberg, J.R. Bears show a physiological but limited behavioral response to unmanned aerial vehicles. Curr. Biol. 2015, 25, 1-6. [CrossRef] [PubMed]

65. Hodgson, J.C.; Koh, L.P. Best practice for minimising unmanned aerial vehicle disturbance to wildlife in biological field research. Curr. Biol. 2016, 26, 404-405. [CrossRef] [PubMed]

(C) 2017 by the authors. Licensee MDPI, Basel, Switzerland. This article is an open access article distributed under the terms and conditions of the Creative Commons Attribution (CC BY) license (http://creativecommons.org/licenses/by/4.0/). 